\title{
Inorganic UV filters
}

\author{
Eloísa Berbel Manaiaㅁ, Renata Cristina Kiatkoski Kaminski², Marcos Antonio Corrêa ${ }^{1}$, \\ Leila Aparecida Chiavacci, ${ }^{1, *}$
}

\author{
${ }^{1}$ Department of Drugs and Medicaments, Faculty of Pharmaceutical Sciences, São Paulo State University, UNESP, \\ ${ }^{2}$ Department of Physical-Chemistry, Institute of Chemistry, São Paulo State University, UNESP
}

\begin{abstract}
Nowadays, concern over skin cancer has been growing more and more, especially in tropical countries where the incidence of UVA/B radiation is higher. The correct use of sunscreen is the most efficient way to prevent the development of this disease. The ingredients of sunscreen can be organic and/or inorganic sun filters. Inorganic filters present some advantages over organic filters, such as photostability, non-irritability and broad spectrum protection. Nevertheless, inorganic filters have a whitening effect in sunscreen formulations owing to the high refractive index, decreasing their esthetic appeal. Many techniques have been developed to overcome this problem and among them, the use of nanotechnology stands out. The estimated amount of nanomaterial in use must increase from 2000 tons in 2004 to a projected 58000 tons in 2020. In this context, this article aims to analyze critically both the different features of the production of inorganic filters (synthesis routes proposed in recent years) and the permeability, the safety and other characteristics of the new generation of inorganic filters.
\end{abstract}

Uniterms: Skin cancer. Sunscreen. Inorganic UV filter.

A preocupação com o câncer de pele hoje em dia vem crescendo cada vez mais principalmente em países tropicais, onde a incidência da radiação UVA/B é maior. O uso correto de protetores solares é a forma mais eficaz de prevenir o aparecimento desta doença. Os ativos utilizados em protetores solares podem ser filtros orgânicos e inorgânicos. Filtros inorgânicos apresentam muitas vantagens em relação aos orgânicos, tais como fotoestabilidade, ausência de irritabilidade e amplo espectro de proteção. Entretanto, em razão de apresentarem alto índice de refração, os ativos inorgânicos conferem aos protetores solares aparência esbranquiçada, diminuindo sua atratividade estética. Muitas alternativas têm sido desenvolvidas no sentido de resolver este problema e dentre elas pode-se destacar o uso da nanotecnologia. Estima-se que o uso de nanomateriais deve crescer das atuais 2000 para 58000 toneladas até 2020 . Neste sentido, este trabalho tem como objetivo fazer a análise crítica abordando diferentes aspectos envolvidos tanto na obtenção de protetores solares inorgânicos (rotas de sínteses propostas nos últimos anos) quanto na permeabilidade, na segurança e em outros aspectos relacionados à nova geração de filtros solares inorgânicos.

Unitermos: Câncer de pele. Protetores solares. Filtros inorgânicos.

\section{INTRODUCTION}

Concern about skin cancer preoccupation has been growing more and more, particularly in tropical countries where the ultraviolet (UV)A/B radiation is stronger. According to the Brazilian Instituto Nacional do Câncer (INCA), for the year 2012 the estimate is 134170 new

\footnotetext{
*Correspondence: L.A. Chiavacci. Departamento de Fármacos e Medicamentos, Faculdade de Ciências Farmacêuticas, Universidade Estadual Paulista "Júlio de Mesquita Filho”. Rod. Araraquara, km 1. Bairro Jaú, 14800-900 - Araraquara - SP, Brasil. E-mail: leila@fcfar.unesp.br
}

cases of nonmelanoma skin cancer and 6230 new cases of melanoma (Brasil, 2013a,b). Sunscreen, correctly used, is the most effective means of preventing this disease from developing and studies in this area focus on the safety, effectiveness and improvement of these products (Lahmann, Russell, Green, 2011; Paula et al., 2012).

The active components of sunscreen can be organic and inorganic UV filters, which are able to transform, disperse or absorb the ultraviolet radiation. Typically, the organic UV filters are called chemical filters, as their mode of action is related to chemical changes in their molecules that prevent UV radiation reaching the skin. The inorganic 
UV filters are called physical, because their mode of skin protection against solar radiation is associated with physical phenomena, such as scattering and reflection of UV radiation (Antoniou et al., 2008; Jin et al., 2008; Seite et al., 2000; Van der Pols et al., 2006; Wang, Balagula, Osterwalder, 2010). However, the correct denomination of UV filters is inorganic and organic, because both of them are chemical products differing in their molecular composition and physical and chemical terms refer to the action mode of the UV filters (Morabito et al., 2011).

The most frequently used inorganic UV filters are titanium dioxide $\left(\mathrm{TiO}_{2}\right)$ and zinc oxide $(\mathrm{ZnO})$. These oxides have been prepared in nanometric particles, which show the least reflection of visible radiation, thus producing less effect of white coloration when applied to the skin, and also have special properties from the viewpoint of photoprotective efficacy. The use of nanomaterials has increased exponentially in recent years, rising from 2,000 tons produced in 2004 to 58,000 tons in 2011-2020 (Mileyeva-Biebesheimer, Zaky, Gruden, 2010).

Given the increasing interest in developing sunscreen formulations, the aim of this paper is to make a review of the different forms of sun protection available, emphasizing the differences between inorganic and organic UV filters.

\section{SKIN CANCER AND SUN RADIATION}

Skin cancer is the most common in Brazil, representing $25 \%$ of malignant tumors recorded in all regions of the country. The melanoma skin cancer is the most serious because it can initiate metastasis. However, if it is diagnosed at an early stage, there is a great chance of achieving a cure. Non-melanoma skin cancer is more common than melanoma and can originate in various cells lines, such as basal cell or squamous cell. In Brazil, melanoma skin cancer was responsible for 1507 deaths in 2010 and non-melanoma skin cancer for 1521 deaths in 2010 (Brasil, 2013a,b). In the USA in 2006, more than two million people received treatment for non-melanoma skin cancer (American, 2010).

Exposure to sun ultraviolet radiation (UV) is the main etiological cause of skin cancer (Klug et al., 2010). Two components of solar UV are UVA and UVB, both of which pass through the ozone layer (Wang, Balagula, Osterwalder, 2010) and induce skin cancer (Duale et al., 2010). UVA radiation is responsible for skin pigmentation and it is subdivided into UVA I (wavelength range 320$340 \mathrm{~nm}$ ) and UVA II (wavelength range 340-400 nm). UVB radiation can also induce the pigmentation but it has higher energy due to its shorter wavelength, between 290-320 nm and is the mainly responsible for skin sunburns (Flor, Davolos, Correa, 2007). The molecular mechanisms by which UV radiation triggers skin cancer involve direct or indirect DNA damages, by forming pyrimidine dimers, photoproducts or reactive oxygen species (ROS) or by promoting the cell cycle arrest, immune depression, cellular apoptosis or transcriptional changes (Klug et al., 2010). Furthermore, UVA radiation penetrates deeper into the skin, reaching the dermis and leading to the onset of many age-related skin alterations. UVB radiation is the mainly responsible for immediate damage to the skin, which leads to erythema and sunburns (Jain, Jain, 2010), besides the possibility of attacking directly the cell DNA, with subsequent potential to induce changes that characterize skin cancer.

There are some environmental factors that influence the intensity of the UV radiation reached the Earth's surface such as ozone levels, cloud cover and height, environmental pollutants, altitude, latitude and the seasons of the year (Palm, O'Donoghue, 2007; Balogh et al., 2011). The ozone layer, capable of photoabsorption, situated approximately $40 \mathrm{~km}$ above the surface of the earth, holds back approximately $100 \%$ of the UVC radiation (200-290 nm) and $90 \%$ of the UVB, while all the UVA radiation reaches the Earth's (Wang, Balagula, Osterwalder, 2010). It is important to note that UV radiation not absorbed by the ozone layer may be penetrated by water in the rate of $80 \%$ and the UVB radiation may be reflected up the UV radiation to the skin by sand, snow and concrete at a rate of 90\% (Palm, O'Donoghue, 2007; Wang, Balagula, Osterwalder, 2010). The altitude can influence the UV intensity presenting an increase of $4 \%$ of UV radiation that reaches the surface for every $300 \mathrm{~m}$ of elevation (Rigel, Rigel, Rigel, 1999). Each degree of decrease in latitude can raise $3 \%$ in the transmission of UVB rays. Farther weather factors, for example, fog, clouds and pollution can ardently reduce UV transmission by 10 to $90 \%$ (Kromann, 1986).

The ozone layer has been declined annually, mainly in the Southern hemisphere, due to the emission of chlorofluorocarbons. This decrease reflects directly in the amount of UV radiation reached in the Earth (Balogh et al., 2011). Studies have been estimated the relation of ozone level depletion and the consequences in the skin health: each $1 \%$ of decrease in the ozone level increases $1 \%$ to $2 \%$ the amount of UVB radiation in the planet surface. The association of this data with the incidence of skin cancer due to increased UVB radiation showed that each $1 \%$ of decrease in ozone level provoke an quantitative increase of skin cancer risk at about $1.6 \%$ for squamous cell carcinoma and $1 \%$ for basal cell carcinoma (Clarke, 2006).

Even though UVC radiation has some desirable 
properties, such as germicidal activity, reports show that UVC radiation can be harmful to the skin, as it exhibits potential mutagenic and carcinogenic activity (Jain, Jain, 2010). Some studies on the ozone layer have stimulated rising concern among the scientific community, mainly grounded on its increasing destruction, but also because there are only a few studies that report the quantity of UVC radiation that currently crosses the ozone layer and while the sunscreens on the market are not active at the wavelength of UVC rays.

Various measures can be taken to prevent skin cancer, some of which include avoiding exposure to solar radiation at times of highest incidence of UV radiation, mainly between 10 am and $3 \mathrm{pm}$, using accessories such as hats, sunglasses with UV protection and umbrellas, but the correct use of sunscreens with an appropriate sun protection factor (SPF) is still the most efficient way of preventing skin cancer (Klug et al., 2010; United, 2011). An Australian study has shown that the regular use of sunscreens can help in the prevention of squamous cell carcinoma (a type of skin cancer) of head, neck and forearm (Van der Pols et al., 2006). Given the importance of photoprotection and skin disease prevention, the effectiveness of sunscreens products has been the object of more and more studies. Apart from this, the need for frequent application of the right amount of sunblock makes it desirable that, in addition to efficiently stopping the UV radiation, it should have other properties that are crucial to the acceptability of the product. These include easy spreading, prolonged retention on the skin, transparency, low cost and attractive appearance, all of which are needed for the product be completely accepted. Combining these characteristics in one product is not always possible, so that, despite the great number of sunscreens on the market, the development of new formulations remains a research area that attract many scientists and companies.

\section{ORGANIC X INORGANIC UV FILTERS}

Sunscreen is not only an important weapon against skin cancer, but is also designed to alleviate other skin processes induced by solar radiation, such as aging, wrinkle formation, undesired pigmentation and collagen loss (Duale et al., 2010; Seite et al., 2000). There are two groups of active molecules that can act as UV filters: organic and inorganic. The inorganic UV filters such as zinc oxide, titanium dioxide, iron oxide, kaolin, ichthammol, red veterinary petrolatum, talc, calaminein (Lowe, 2006), phosphate and carbonates based nanomaterials and pure and doped hydroxyapatite (Araujo, Souza, 2008) scatter, reflect and/or absorb the sun's radiation that reaches the skin. Currently, in the United States and in Brazil there are only two inorganic filters, titanium dioxide and zinc oxide, approved by the FDA (Wang, Balagula, Osterwalder, 2010) and by ANVISA (Brasil, 2006), respectively, and by this reason they are the UV filters in commercial use (González, Fernández-lorente, Gilaberte-Calzada, 2008), which we will empathize the discussion in this paper. The organic UV filters are usually aromatic compounds with a carbonyl group. On receiving the energy of UV photons, the organic UV filters can act in three ways: (i) undergo conformational molecular changes, (ii) emit radiation at higher wavelength or (iii) release incident energy as heat (Antoniou et al., 2008; Kiss et al., 2008). The action mode of the organic protector molecules is reversible, so that the same molecule can function repeatedly. Examples of organic sunscreens are salicylates, cinnamates, benzophenones, anthranilates, dibenzoylmethanes and p-aminobenzoates (Antoniou et al., 2008; Jain, Jain, 2010). Figure 1 illustrates the different modes of action of the organic and inorganic UV filters.

Both inorganic and organic UV filters are able to protect skin from UVA and UVB. Nevertheless, not all

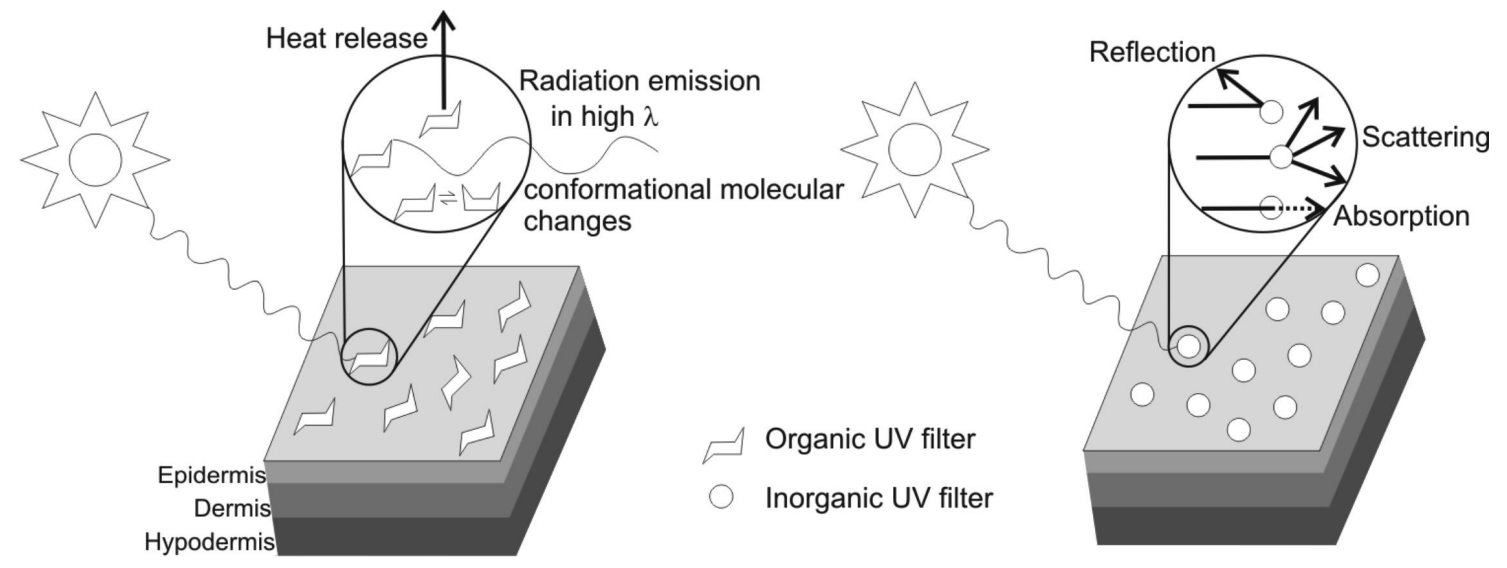

FIGURE 1 - Action mode of organic (left) and inorganic (right) UV filters. 
the organic UV filters absorb both UV bands and many absorb only UVB radiation. The inorganic UV filters offer some highly relevant advantages over the organic ones: they give broader spectrum protection (covering UVA and UVB), are photostable while some organic UV filters (for example, avobenzone) are not photostable and provoke lower allergenicity and sensitization (Wang, Balagula, Osterwalder, 2010). This last factor justifies their wide use in sunscreens for children (Serpone, Dondi, Albini, 2007), which tends to cause less skin irritation than the organic UV filters (Choi et al., 2011). Furthermore, on absorbing the UV photons, organic UV filters can release free radicals and consequently cause damage to collagen, elastin or skin cell DNA. Thus, the frequent use of organic UV filters could be questioned on safety grounds, since their utilization right causes non negligible adverse reactions (Jain, Jain, 2010).

Although the literature suggests that the use of sunscreen could reduce vitamin D production to an insufficient level, as this important vitamin needs UV irradiation of the skin to transform a precursor into provitamin $\mathrm{D}_{3}$, recent studies show that this does not happen. These studies not only point out that sunscreens do not block all UV radiation, but also suggest that it is not true that all of the skin exposed to sunlight is protected by the sunscreen. The most relevant factor to consider is the fact that people do not use the correct amount for one application. Actually, the SPF for sunscreen formulations, determined by the technical regulations, established in vivo application, specify the use of $2 \mathrm{mg}$ of product per $\mathrm{cm}^{2}$ of skin, but it is observed that people do not apply this amount of sunscreen. Other factors, such as the level of sweating and breathing, for example, should also be considered (Norval, Wulf, 2009).

According to the Brazilian regulatory agency, Agência Nacional de Vigilência Sanitária (ANVISA), the SPF is defined by the ratio between the minimal erythematous dose (MED) on the skin protected by sunscreen and the MED on the same skin unprotected. MED is defined as the minimal dose of UV radiation required to raise the first perceptible erythematous reaction with clearly defined edges on the skin. For sunscreen registration, two in vivo procedures or actualizations are accepted by ANVISA: (i) COLIPA/JCIA/CTFA-SA international sun protection factor (SPF) test method (2006) and (ii) FDA (Food and Drug Administration) sunscreen drug products for overthe-counter human use, final monograph 21 CFR part 352 (1999). In Brazil, the SPF is defined in four categories: low protection (SPF between 6 and 14.9), moderate protection (SPF between 15 and 29.9), high protection (SPF between 30 and 50) and very high protection (SPF between 50 and 100) (Brasil, 2012).
Besides SPF, there is the UVA protection factor (PF-UVA), which relates the minimum pigmentary dosage (MPD) of the skin protected by sunscreen to the MPD of unprotected skin. MPD is defined as the minimal dose of UVA radiation required to cause persistent pigment darkening of the skin with clearly defined edges after $2-4 \mathrm{~h}$ of UVA radiation exposure. It is necessary for the UVA protection factor $(\mathrm{PF})$ to be at least $1 / 3$ of UVB PF, at the critical wavelength of $370 \mathrm{~nm}$, so that the product label can display in writing "UVA protector". The procedures or actualizations required by ANVISA to test PF-UVA can be the in vivo method developed by the European Commission, Standardization mandate assigned to CEN concerning methods for testing efficacy of sunscreen products, annex 2 (2006) or the in vitro method developed by COLIPA, In vitro method for the determination of the UVA protection factor and "critical wavelength" values of sunscreen products, in 2009 (Brasil, 2012).

\section{INORGANIC UV FILTERS: $\mathrm{TiO}_{2}$ AND $\mathrm{ZnO}$}

Titanium dioxide is an inorganic UV filter which acts by scattering, reflecting and/or absorbing the UV radiation, protecting skin cell DNA from being damaged by this radiation. $\mathrm{TiO}_{2}$ is declared safe in concentrations up to $25 \%$ of the formulation by weight, both by ANVISA and the United States Pharmacopeia (USP) (Sadrieh et al., 2010).

Besides been used as UV filter, $\mathrm{TiO}_{2}$ has also been applied in self-cleaning coatings for windows (Sayes et al., 2006), orthopedic prostheses, plastic products (Kiss et al., 2008) and on the nanoscale has been used in many products, such as paints, textiles, electronic devices and pharmaceutical products. It also shows photocatalytic activity and on account of this property, it has been used to treat pollutants and waste water and has been investigated as a tumor cells destructive agent (Jacobs, Poel, Osseweijer, 2010). As a result of the catalytic activity stimulated by UV radiation, superoxide and hydroxyl radicals are formed on the particle surface, surrounded by water. DNA controls the cell cycle organization and reactive oxygen species (ROS) are able to cause damage to DNA in tumor cells, interfering with their normal operation and potentially causing cell death (Kiss et al., 2008). Nevertheless, the small amount of ROS generated by UV irradiation, as well as their shorter half-lives, are inadequate to cause tumor tissue death continuously. In addition, the UV radiation would not reach a cancer located in deeper regions. Hence other energy sources have been sought, and the use of ultrasound waves on $\mathrm{TiO}_{2}$ has been shown effective in combating tumor cell proliferation (Harada et al., 2011). Although $\mathrm{TiO}_{2}$ used jointly with 
UV radiation or ultrasound are regarded as promising therapies, they have some clinical inconveniences, e.g. low selectivity. In this direction, many attempts to improve these systems have been made, for example combining $\mathrm{TiO}_{2}$ with antibodies (Xu et al., 2007) or encapsulating $\mathrm{TiO}_{2}$ in liposomes (Chihara et al., 2007), in order to produce cell death in cancer tissue alone.

Zinc oxide also displays photocatalytic activity. There are studies that assess both $\mathrm{TiO}_{2}$ and $\mathrm{ZnO}$ for their ability to act as a bactericidal agent. They have been shown to be effective against Bacillus subtilis, Escherichia coli, Pseudomonas aeruginosa and Streptococcus aureus. One way to cause bacterial death is by depletion of the bilipid layer of some bacteria via reactive oxygen species formed by these oxide nanoparticles (Mileyeva-Biebesheimer, Zaky, Gruden, 2010).

$\mathrm{TiO}_{2}$ has three crystalline forms, named anatase, rutile and brookite (Sadrieh et al., 2010), but only anatase and rutile are useful for sunscreen formulations (Serpone, Dondi, Albini, 2007). Anatase is the most photoactive polymorphic form of $\mathrm{TiO}_{2}$, having a higher photocatalytic activity than rutile. The structure of the nanoparticles, specially their surface, plays a prominent role in their chemical reactivity and other properties. Many studies have compared anatase and rutile for their cytotoxicity and capacity to form reactive species, in terms of their photocatalytic properties. According to one of this studies, anatase adsorbs dissociated water molecules while rutile adsorbs non-dissociated ones, making anatase more able to react with $\mathrm{OH} \cdot$ reactive species when it is under UV radiation. The results revealed that the less active catalytic material, rutile, showed 100 times less cytotoxicity than anatase nanoparticles of a similar size, which exhibited high photoactivity. Therefore, it has been suggested that the oxidative damage induced by UV radiation in photocatalysis is strongly affected by the polymorphic form of titanium nanoparticles and the reactive species formed by nanocrystals are effective in breaking cell functionality (Sayes et al., 2006).

The UV protection spectral range provided by $\mathrm{TiO}_{2}$ is broad, extending from UVA II to UVB region (Serpone, Dondi, Albini, 2007), while the $\mathrm{ZnO}$ protection range peaks in the UVA spectrum (Popov et al., 2008). Thus, $\mathrm{ZnO}$ is used as a complement to UVB attenuators, thereby, affording preparations that provide broad spectrum protection all day long. However, $\mathrm{TiO}_{2}$ can be used alone because it offers protection across the spectrum. Figure 2 shows the absorption spectra of $\mathrm{TiO}_{2}$ and $\mathrm{ZnO}$.

It should be recalled that the ozone layer is being destroyed by substances such as chlorofluorocarbons

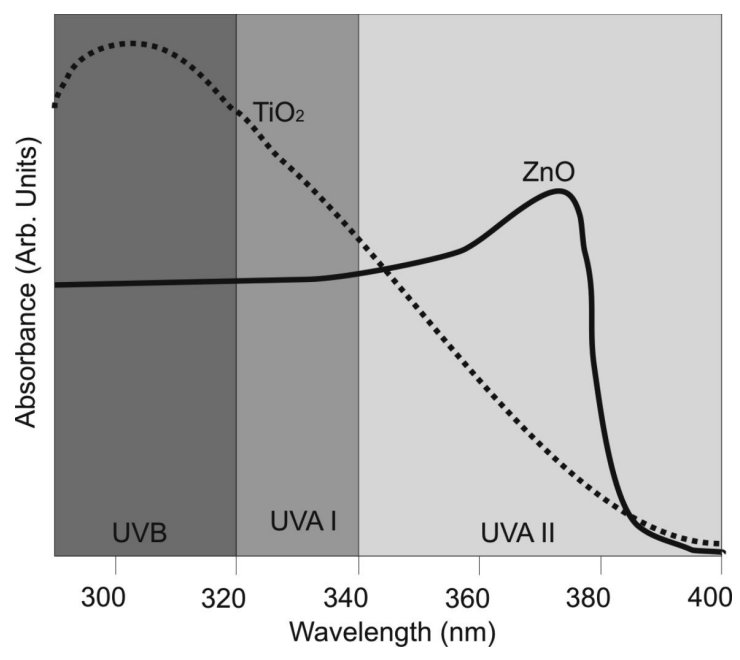

FIGURE 2 - Schematic demonstration of UVA and UVB absorbance by $\mathrm{TiO}_{2}$ and $\mathrm{ZnO} \mathrm{UV}$ filters.

(CFCs), resulting in increased UV irradiation on the surface of the planet (Wang, Balagula, Osterwalder, 2010). Thus, the UVC radiation, of shorter wavelength (200-290 nm) and therefore more energy, must be taken into account in the products offering sun protection in the near future. For this propose, inorganic UV filters are very promising, because they can certainly scatter or reflect this kind of radiation. Up to now, there has been limited availability in the market of organic molecules that absorb well in this UV spectral range.

One of the known unfavorable characteristics of these oxides in sunscreen formulations is their capacity to make a white film. This is due to two special properties of these materials: the first is the large size of the particles (above $200 \mathrm{~nm}$ ), allowing reflection not only of UV radiation but also of visible light (wavelength between 400 $-700 \mathrm{~nm}$ ), and the second property, which is immutable, is their high refraction index (2.6 for $\mathrm{TiO}_{2}$ and 1.9 for $\mathrm{ZnO}$ ). Therefore, many manufacturers are producing micronized or sub-micronized inorganic UV filters (nanosized particles), because reducing the particle size improves the appearance of commercial sunscreens and enhances radiation absorption, enabling their utilization in cosmetic formulations such as lotions and emulsions for sunscreens (Kiss et al., 2008; Sadrieh et al., 2010; Serpone, Dondi, Albini, 2007; Wang, Balagula, Osterwalder, 2010). Particle sizes between 15 and $50 \mathrm{~nm}$ can display a less opaque appearance, due to their poor capacity to reflect UV-Vis radiation (Allen et al., 2002).

The size and surface area of $\mathrm{TiO}_{2}$ particles have considerable effect on their solar radiation attenuation power, following the Mie law (Sadrieh et al., 2010). Mie Law was elucidated for spherical particle light scatter 
(Jonssona et al., 2004) and gives the scattered intensity as a function of arbitrary polarization scattering angle. The equations describing this scattering are very complex, involving a combination of Legendre polynomials and Ricatti-Bessel and Hankel functions, but software can be employed to facilitate these calculations (Sorensen, Fischbach, 2000). The Mie theory has been used to determine the $\mathrm{TiO}_{2}$ particle size that protects best at specific wavelengths using calculations: particles between 20 and $100 \mathrm{~nm}$ attenuate radiation best at wavelength 290 $\mathrm{nm}$ (UVB), particles between 80 and $160 \mathrm{~nm}$ attenuate the wavelength $350 \mathrm{~nm}$ (UVA) and particles between 120 and $180 \mathrm{~nm}$ attenuate at wavelength $400 \mathrm{~nm}$ (UVA) (Popov et al., 2008). Mie Law gives a general solution for diffusion radiation, while Rayleigh scattering relates the particle radius to the scattering intensity at a given wavelength, for very small particles. According to Rayleigh scattering, the radiation scattering intensity is inversely proportional to the fourth power of the wavelength. Therefore, at a wavelength below $400 \mathrm{~nm}$, the UV dispersion is better when the particles are finer (Allen et al., 2002).

The great concern of researches regarding the size of $\mathrm{TiO}_{2}$ nanoparticles relates not only the effectiveness of photoprotection, but also to the fact that it could harm human health. Owing to their small size, $\mathrm{TiO}_{2}$ nanoparticles have several ways to enter the human body: inhalation (respiratory tract), ingestion (gastrointestinal tract), dermal penetration (skin) and others (Jin et al., 2008). In vitro tests on pig skin, which is widely used for its similarities to human skin, showed that topically applied nanosized titanium dioxide and zinc oxide formulations were not capable of permeating the intact normal skin (Gamer, Leibold, Van Ravenzwaay, 2006). At present there is no evidence that topical applications of $\mathrm{TiO}_{2}$ are liable to cause pathogenic changes in the skin. It is believed that the skin can perform its protective function by means of the keratinocytes located in the epidermis stratum corneum, which prevent the penetration of $\mathrm{TiO}_{2}$ to deeper layers of the skin. Another experiment performed with intact human skin showed that the $\mathrm{TiO}_{2}$ nanoparticles did not penetrate the stratum corneum. Nevertheless, when $\mathrm{TiO}_{2}$ is in contact with damaged stratum corneum, nanoparticles can be internalized by some skin cells; in this study, internalization in fibroblast and melanocyte was identified, which can affect the epidermal differentiation mechanism and/or be cytotoxic (Kiss et al., 2008). Therefore, it is concluded that until now the studies carried out on topical application of $\mathrm{TiO}_{2}$ and $\mathrm{ZnO}$ have shown that these materials can be safely used because they do not have the capacity to permeate the skin in significant quantities.

Titanium dioxide may be incorporated into several types of cosmetic sunscreen formulations, such as emulsions, lotions, sprays and gels (Jain, Jain, 2010). Among such marketed preparations, the emulsions are unquestionably the main vehicle for the incorporation of inorganic UV filters like $\mathrm{TiO}_{2}$. Usually, the creams containing $\mathrm{TiO}_{2}$ are emulsions with an aqueous phase, an oil phase and a surfactant which are mixed uniformly to form a stable cream. However, there is a great tendency for $\mathrm{TiO}_{2}$ particles, particularly nanoparticles, to be nonuniformly distributed and to form clumps (Oh et al., 2010), hindering the smooth spreading of the formulation on the skin and thus preventing the formation of an even film over the exposed area and thereby reducing the sunscreen efficiency and the esthetic attractiveness of the product. The energy available in the process of homogenizing the emulsion is not sufficient to disrupt the clumps formed. This tendency of the $\mathrm{TiO}_{2}$ nanoparticles to aggregate is due to van der Waals forces, electrostatic forces, hydrogen bonds and interactions with water molecules adsorbed on the nanoparticle surface (Schlossman, Shao, 2005). Petryshyn and co-workers have shown that the properties of suspended $\mathrm{TiO}_{2}$ can be controlled by $\mathrm{pH}$ and by the type of surfactant. In this study, the nonionic surfactant had no influence on the surface charge density or the aggregation capacity of the particles, but the same behavior was not observed when ionic surfactants were employed, since these materials altered the $\mathrm{pH}$ of the formulation and thus the nanoparticle surface charge (Petryshyn, Yaremko, Soltys, 2010), resulting in changes to the aggregation process. The cosmetic base of synthetic or natural polymer gel has a transparent look, however, on adding these inorganic UV filters, even as microparticles, leads to formation of a turbid gel, due to the white color of $\mathrm{TiO}_{2}$ and $\mathrm{ZnO}$, since they are insoluble oxides and may form large aggregates (Flor, Davolos, Correa, 2007).

Most of the sunscreens on the market have inorganic and organic UV filters in their formulations. Since most sunscreens offer intense protection in a specific region of the UV spectrum, it is necessary to combine small amounts of differing UV filters to provide a desired SPF. However, when looking for a sunscreen with a lower allergenic potential, the best UV filters are the inorganic ones which, however, are more difficult to incorporate and demand more technical care to maintain stability. Researchers in this field are continually searching for further improvements in sunscreen formulations such as new active molecules and/or possible new combinations, and also developing new innovative cosmetic systems (Jain, Jain, 2010). For $\mathrm{TiO}_{2}$, silica, alumina or polymer coatings have been used to increase the stability in lotions and creams. However, this is a questionable practice, 
because it could reduce the photoactivity and the coating durability is unknown (Jacobs, Poel, Osseweijer, 2010). On way of enhancing their function is to employ these materials in nanoparticulate size. U.S. patent 20087326399 defines $\mathrm{TiO}_{2}$ nanoparticles with a controlled size that may be used as a suspension or powder. These nanoparticles are obtained by reacting an inorganic titanium-based compound with water or ice to form an aqueous titanium compound that reacts with a dispersant (Headwaters, 2008). Our group has shown the possibility of preparing $\mathrm{TiO}_{2}$ nanoparticles with a surface modified by $p$-toluene sulphonic acid (PTSH), via the sol-gel process. The nanoparticles exhibit transparency at temperatures varying from 25 to $60^{\circ} \mathrm{C}$ thus being very attractive to the cosmetic market (Kaminski et al., 2010). Cell viability tests have been done with the $\mathrm{TiO}_{2}$ nanoparticles capped by PTSH, revealing low cytotoxicity to keratinocytes and human fibroblasts. Furthermore, it was possible to incorporate these nanoparticles into liquid-crystal systems without affecting the ordered structure of these formulations (Manaia et al., 2012).

\section{ACKNOWLEDGMENT}

We thank FAPESP and CNPq for the finnancial support.

\section{REFERENCES}

ALLEN, N.S.; EDGE, M.; ORTEGA, A.; LIAUWA, C.M.; STRATTONB, J.; MCINTYRE, R.B. Behaviour of nanoparticle (ultrafine) titanium dioxide pigments and stabilisers on the photooxidative stability of water based acrylic and isocyanate based acrylic coatings. Polym. Degrad. Stab., v.78, n.3, p.467-478, 2002.

AMERICAN CANCER SOCIETY. Cancer facts \& figures 2010. Atlanta: American Cancer Society, 2010. p.1-62.

ANTONIOU, C.; KOSMADAKI, M.G.; STRATIGOS, A.J.; KATSAMBAS, A.D. Sunscreens - what's important to know. J. Eur. Acad. Dermatol. Venereol., v.22, n.9, p.1110$1118,2008$.

ARAUJO, T.S.; SOUZA, S.O. Protetores solares e os efeitos da radiação ultravioleta. Scientia Plena, v.4, n.11, p.1-7, 2008.

BALOGH, T.S.; VELASCO, M.V.R.; PEDRIALI, C.A.; KANEKO, T.M.; BABY, A.R. Ultraviolet radiation protection: current available resources in photoprotection. An. Bras. Dermatol., v.86, n.4, p.732-742, 2011.
BRASIL. Ministério da Saúde. Instituto Nacional de Câncer. Câncer tipo pele melanoma, 2013a. Available at: http:// www2.inca.gov.br/wps/wcm/connect/tiposdecancer/site/ home/pele_melanoma. Accessed on: 17 Jan. 2013.

BRASIL. Ministério da Saúde. Instituto Nacional de Câncer. Câncer tipo pele não melanoma, 2013b. Available at: http:// www2.inca.gov.br/wps/wcm/connect/tiposdecancer/site/ home/pele_nao_melanoma. Accessed on: 17 Jan. 2013.

BRASIL. Resolução n.47, de 16 de março de 2006. Regulamento técnico Lista de filtros ultravioletas permitidos para produtos de higiene pessoal, cosméticos e perfumes. Brasília: Diário Oficial da União, 17 Mar. 2006.

BRASIL. Resolução n.30, de 1 de junho de 2012. Regulamento técnico MERCOSUL sobre protetores solares em cosméticos. Brasília: Diário Oficial da União, 4 June 2012.

CHIAHARA, Y.; FUJIMOTO, K.; KONDO, H.; MORIWAKA, Y.; SASAHIRA, T.; HIRAO, Y.; KUNIYASU, H. Antitumor effects of liposome-encapsulated titanium dioxide in nude mice. Pathobiology, v.74, n.6, p.353-358, 2007.

CHOI, Y.G.; LEE, J.H.; BAE, I.H.; AH, Y.C.; KI, H.M.; BAE, J.H.; PARK, Y.H.; LEE, K.C.; LIM, K.M. Titanium dioxide inclusion in backing reduce the photoallergenicity of ketoprofen transdermal patch. Arch. Toxicol., v.85, n.3, p.219-226, 2011.

CLARKE, F.S. The relationship between the ozone layer and skin câncer. Rev. Méd. Chile, v.134, n.9, p.1185-1190, 2006.

DUALE, N.; OLSEN, A.K.; CHRISTENSEN, T.; BUTT, S.T.; BRUNBORG, G. Octyl methoxycinnamate modulates gene expression and prevents cyclobutane pyrimidine dimer formation but not oxidative DNA damage in UV-exposed human cell lines. Toxicol. Sci., v.114, n.2, p.272-284, 2010.

FLOR, J.; DAVOLOS, M.R.; CORREA, M.A. Protetores solares. Quím. Nova, v.30, n.1, p.153-158, 2007.

GAMER, A.O.; LEIBOLD, E.; VAN RAVENZWAAY, B. The in vitro absorption of microfine zinc oxide and titanium dioxide through porcine skin. Toxicol. In Vitro, v.20, n.3, p.301-307, 2006.

GONZÁLEZ, S.; FERNÁNDEZ-LORENTE, M.; GILABERTECALZADA, Y. The latest on skin photoprotection. Clin. Dermatol., v.26, n.6, p.614-26, 2008. 
HARADA, Y.; OGAWA, K.; IRIE, Y.; ENDO, H.; FERIL JR, L.B.;UEMURA, T.; TACHIBANA, K. Ultrasound activation of TiO2 in melanoma tumors. $J$. Controlled Release, v.149, n.2, p.190-195, 2011.

HEADWATERS TECHNOLOGY INNOVATION, LLC (United States) ZHOU, B.; PARASHER, S.; WU, Z.; ZHOU, Z. Titanium dioxide nanoparticles and nanoparticle suspensions and methods of making the same. US Pat. 20087326399, 2005.

JACOBS, J.F.; POEL, I.V.; OSSEWEIJER, P. Sunscreens with titanium dioxide $\left(\mathrm{TiO}_{2}\right)$ nano-particles: a societal experiment. Nanoethics, v.4, n.2, p.103-113, 2010.

JAIN, S. K.; JAIN, N.K. Multiparticulate carriers for sunscreening agents. Int. J. Cosmet. Sci., v.32, n.2, p.89-98, 2010.

JIN, C.Y.; ZHU, B.S.; WANG, X.F.; LU, Q.H. Cytotoxicity of titanium dioxide nanoparticles in mouse fibroblast cells. Chem. Res. Toxicol., v.21, n.9, p.1871-1877, 2008.

JONSSONA, J.C.; KARLSSONA, L.; NOSTELLA, P.; NIKLASSONA, G.A.; SMITH, G.B. Angle-dependent light scattering in materials with controlled diffuse solar optical properties. Solid Energy Mater. Sol. C., v.84, n.1-4, p.427-439, 2004.

KAMINSKI, R.C.K.; PULCINELLI, S.H.; JUDEINSTEIN, P.; MENEAU, F.; BRIOIS, V.; SANTILLI, C.V. Thermoreversible sol-gel transition of surface modified titanium poly oxo building blocks. J. Phys. Chem. C., v.114, n.3, p.1416-1423, 2010.

KISS, B.; BÍRÓ, T.; CZIFRA, G.; TÓTH, B.; KERTÉSZ, Z.; SZIKSZAI, Z.; KISS, A.Z.; JUHÁSZL, I.; ZOUBOULIS, C.C.; HUNYADI, J. Investigation of micronized titanium dioxide penetration in human skin xenografts and its effect on cellular functions of human skin-derived cells. Exp. Dermatol., v.17, n.8, p.659-667, 2008.

KLUG, H.L.P.; TOOZE, J.A.; CHERRY-GRAFF, C.; ANVER, M.R.; NOONA, F.P.; FEARS, T.R.; TUCKER, M.A.; FABO, E.C.; MERLINO, G. Sunscreen prevention of melanoma in man and mouse. Pigm. Cell Melanoma Res., v.23, n.6, p.835-837, 2010.
KROMANN, N.; WULF, H.C.; ERIKSEN, P.; BRODTHAGEN, H. Relative ultraviolet spectral intensity of direct solar radiation, sky radiation and surface reflections. Relative contribution of natural sources to the outdoor UV irradiation of man. Photodermatol., v.3, n.2, p.73-82, 1986.

LAHMANN, P.H.; RUSSELL, A.; GREEN, A.C. Prospective study of physical activity and risk of squamous cell carcinoma of the skin. BMC Cancer, v.11, n.516, p.1-9, 2011.

LOWE, N.J. An overview of ultraviolet radiation, sunscreens, and photo-induced dermatoses. Dermatol. Clin., v.24, n.1, p.9-17, 2006.

MANAIA, E.B.; KAMINSKI, R.C.K.; SOARES, C.P.; MENEAU, F.; PULCINELLI, S.H.; SANTILLI, C.V.; CHIAVACCI, L.A. Liquid crystalline formulations containing modified surface $\mathrm{TiO}_{2}$ nanoparticles obtained by sol-gel process. J. Sol-Gel Sci. Technol., v.63, n.2, p.251-257, 2012.

MILEYEVA-BIEBESHEIMER, O.N.; ZAKY, A.; GRUDEN, C.L. Assessing the impact of titanium dioxide and zinc oxide nanoparticles on bacteria using a fluorescent-based cell membrane integrity assay. Environ. Eng. Sci., v.27, n.4, p.329-335, 2010.

MORABITO, K.; SHAPLEY, N.C.; STEELEY, K.G.; TRIPATHI, A. Review of sunscreen and the emergence of non-conventional absorbers and their applications in ultraviolet protection. Int. J. Cosmet. Sci., v.33, n.5, p.385390, 2011.

NORVAL, M.; WULF, H.C. Does chronic sunscreen use reduce vitamin $\mathrm{D}$ production to insufficient levels? $\mathrm{Br} . J$. Dermatol., v.161, n.4, p.732-736, 2009.

OH, C.; YOON, S.; KIM, E.; HAN, J.; CHUNG, H.; JEONG, $\mathrm{H}$. Non destructive determination of tio2 concentration in cream formulation using raman spectroscopy. J. Pharm. Biomed. Anal., v.53, n.3, p.762-766, 2010.

PALM, M.D.; O`DONOGHUE, M.N. Update on photoprotection. Dermatol. Ther., v.20, n.5, p.360-376, 2007.

PAULA, L.R.D.; PARUSSULO, A.L.A.; ARAKI, K.; TOMA, H.E. Evaluation of sun protection factor of cosmetic formulations by a simple visual in vitro method mimicking the in vivo method. J. Pharm. Sci., v.101, n.2, p.726-732, 2012. 
PETRYSHYN, R.S.; YAREMKO, Z.M.; SOLTYS, M.N. Effects of surfactants and ph of medium on zeta potential and aggregation stability of titanium dioxide suspensions. Colloid. J., v.72, n.4, p.512-517, 2010.

POPOV, A.P.; PRIEZZHEV, A.V.; LADEMANN, J.; MYLLYLA, R. Monte Carlo calculations of UV protective properties of emulsions containing $\mathrm{TiO} 2, \mathrm{Si}$ and $\mathrm{SiO} 2$ nanoparticles. Proc. SPIE, v.7022, n.1, p.702211, 2008.

RIGEL, D.S.; RIGEL, E.G.; RIGEL, A.C. Effects of altitude and latitude on ambient UVB radiation. J. Am. Acad. Dermatol., v.40, n.1, p.114-116, 1999.

SADRIEH, N.; WOKOVICH, A.M.; GOPEE, N.V.; ZHENG, J.; HAINES, D.H.; PARMITER, D.; SIITONEN, P.; COZART, C.R.; PATRI, A.K.; MCNEIL, S.E.; HOWARD, P.C.; DOUB, W.H.; BUHSE, L. Lack of significant dermal penetration of titanium dioxide from sunscreen formulations containing nano- and submicron-size $\mathrm{TiO}_{2}$ particles. Toxicol. Sci., v.115, n.1, p.156-166, 2010.

SAYES, C.M.; WAHI, R.; KURIAN, P.A.; LIU, Y.; WEST, J.L.; AUSMAN, K.D.; WARHEIT, D.B.; COLVIN, V.L. Correlating nanoscale titania structure with toxicity: a cytotoxicity and inflammatory response study with human dermal fibroblasts and human lung epithelial cells. Toxicol. Sci., v.92, n.1, p.174-185, 2006.

SCHLOSSMAN D, SHO Y. Sunscreens: regulation and commercial development. 3ed. Boca Raton: Taylor and Francis, 2005. p.239-279.

SEITE, S.; COLIGE, A.; VIVENOT, P.P.; MONTASTIER, C.; FOURTANIER, A.; LAPIÈRE, C.; NUSGENS B. A fullUV spectrum absorbing daily use cream protects human skin against biological changes occurring in photoaging. Photodermatol. Photoimmunol. Photomed., v.16, n.4, p.147-155, 2000.
SERPONE, N.; DONDI, D.; ALBINI, A. Inorganic and organic UV filters: their role and efficacy in sunscreens and suncare products. Inorg. Chim. Acta, v.360, n.3, p.794-802, 2007.

SORENSEN, C.M.; FISCHBACH, D.J. Patterns in mie scattering. Opt. Commun, v.173, n.1-6, p.145-153, 2000.

UNITED STATES OF AMERICA. American academy of dermatology. Skin cancer, 2011. Available at: $<$ http://www. aad.org/skin-conditions/dermatology-a-to-z/skin-cancer>. Accessed on: 27 Feb. 2011.

VAN DER POLS, J.C.; WILLIAMS, G.M.; PANDEYA, N.; LOGAN, V.; GREEN, A.C. Prolonged prevention of squamous cell carcinoma of the skin by regular sunscreen use. Cancer Epidemiol. Biomarkers Prev., v.15, n.12, p.2546-2548, 2006.

XU, J.; SUN, Y.; HUANG, J.; CHEN, C.; LIU, G.; JIANG, Y.; ZHAO, Y.; JIANG, Z. Photokilling cancer cells using highly cell-specific antibody- $\mathrm{TiO}(2)$ bioconjugates and electroporation. Bioelectrochemistry, v.72, n.2, p.217-222, 2007.

WANG, S.K.; BALAGULA, I.; OSTERWALDER, U. Photoprotection: a review of the current and future technologies. Dermatol. Ther, v.23, n.1, p.31-47, 2010.

Received for publication on $31^{\text {st }}$ October 2012 Accepted for publication on $13^{\text {th }}$ March 2013 